DOI $10.15421 / 22186$

Варакута Марина Іванівна, кандидат мистеитвознавства, доиент кафедри „ІІтторія та теорія музики” Дніпропетровської академії музики ім. М. Глінки тел. (097) 998 - 78 - 99 e-mail: amilomarina@i.ua

Гаштова Олена Василівна, магістрант кафедри „Академічний спів" Дніпропетровської академії музики ім. М. Глінки тел. (066) 078 - 42 - 78 e-mail: helena.gashtova@gmail.com

\title{
КОНЦЕРТНА АРІЯ. ІСТОРІЯ РОЗВИТКУ МУЗИЧНОГО ЖАНРУ
}

Метою статті $\epsilon$ історично-хронологічне дослідження етапів розвитку такого музичного феномену, як концертна арія; визначення середовища зародження та занепаду даного вокального жанру. Методологія дослідження формується у взаємодії системного та історичного методів вивчення особливостей виникнення жанру концертної арії. Використання структурноаналітичного методу дозволило зберегти відповідну послідовність викладення матеріалу. Аксіологічний підхід зумовив формування ціннісного критерію щодо відбору художніх прикладів академічного вокального мистецтва у світлі означеної теми дослідження. Наукова новизна полягає у зверненні до маловивченого вокального жанру у світовій музичній культурі, а саме концертної арії. У статті здійснюється диференціація концертної арії та іiї оперного представлення. Означені процеси відбуваються на основі залучення у дослідження найвідоміших шедеврів світового вокального мистецтва. Науковці висвітлюють своєрідні професійно-практичні особливості, специфіку виконання композицій означеного жанру, представляють перспективні напрями подальшого наукового дослідження окресленої теми. Висновки. Вивчення феномену концертної арії як жанру, який 
виник у класичну епоху, має велике значення як для виявлення вокально-стильових особливостей виконання цього жанру, так і для формування поняття „концертної” культури епохи XVIII століття. Концертна арія є унікальним вокальним жанром, який має свої витоки та зв'язок з оперною арією. 3 плином часу, у зв'язку 3 певним розвитком естетики епохи, композиторськими потребами та уподобаннями публіки, означений жанр прийшов до цілковитого занепаду. Перше визначення терміну жанру концертної арії належить до середини XIX століття, лише Г. Шиллінг виявив певні його відмінності від оперної арії та виділив відповідні особливості виконання означеного жанру.

Ключові слова: музичний жанр, вокальна музика, концертна арія, опера, класицизм, співак.

Варакута Марина Ивановна, кандидат искусствоведения, доцент кафедры „История и теория музыки” Днепропетровской академии музыки им. М. Глинки

Гаштова Елена Васильевна, магистрант кафедры „Академический вокал” Днепропетровской академии музыки им. М. Глинки

\section{Концертная ария. История развития музыкального жанра}

Целью статьи является исследование в историческохронологическом разрезе такого музыкального феномена, как концертная ария; выявление среды зарождения и причин упадка данного жанра. Методология исследования формируется во взаимодействии системного и исторического методов изучения особенностей возникновения жанра концертной арии. Использование структурно-аналитического метода позволило сберечь определённую последовательность изложения материала. Аксиологический подход обусловил формирование ценностного критерия относительно отбора художественных примеров академического вокального искусства в свете обозначенной темы исследования. Научная новизна заключается в обращении к малоизученному вокальному жанру в музыковедческой литературе, а именно к концертной арии. В статье осуществляется дифференциация концертной арии и её оперного представления. Отмеченные процессы происходят на основе вовлечения в исследование шедевров мирового академического вокального 
искусства. Учёные освещают своеобразные профессиональнопрактические особенности исполнения композиций данного жанра, представляют перспективные направления дальнейшего исследования заявленной темы. Выводы. Изучение феномена концертной арии, как жанра возникшего в классическую епоху, имеет огромное значение как для выявления вокальностилестических особенностей исполнения музыки отмеченного жанра, так и для формирования понятия „концертной” культуры эпохи XVIII века. Концертная ария является уникальным вокальным жанром, имеющим истоки и связь с оперной арией. С течением времени, в связи с определённым развитием эстетики эпохи, композиторскими потребностями и вкусами публики, данный жанр пришёл к полному упадку. Первое определение термина жанра концертной арии происходит в середине XIX столетия, только Г. Шиллинг выявил его своеобразные отличия от оперной арии и выделил определённые особенности исполнения отмеченного жанра.

Ключевые слова: музыкальный жанр, вокальная музыка, концертная ария, опера, классицизм, певец.

Varakuta Maryna, $\mathrm{PhD}$ in Arts, associated professor of the „History and Theory of Music” chair, Dnipropetrovsk Music Academy after Mikhail Glinka

Gashtova Olena, graduate student of the chair „The academic vocal" of Dnipropetrovsk Music Academy after Mikhail Glinka

\section{Concert aria. The history of development musical genre}

The purpose of this article is the investigation in the historical and chronological perspective of the musical phenomenon such as „Concert aria". The identification of emergence environment and the reasons of the decline in this genre. The research methodology is formed in conjunction systemic and historical methods of studying the peculiarities of the concert aria genre occurrence. The definite sequence of presentment scientific material is saved by employing structure-analytic method. The axiological approach postulated of the process basing for evaluative criteria concerning choosing the artistic examples of academic vocal art in the light delineated theme of the investigation. The scientific novelty lies in an address to the little understood vocal genre in musicology literature, it is concert aria. The concert aria and its 
opera representing is differentiated by researchers in this article. The denoted processes are belonging on the foundation of involving to exploration of outstanding compositions from academic vocal art. Researchers discovers of considerable professionally practical features regarding performing works outlined genre, presents the perspective vectors of the further studying of underscored subject. Conclusions. The examination of the concert aria phenomenon as a genre that has arisen in the classical era, has a great importance both for the vocally - stylistic peculiarities of the genre execution and for the identity building of the "concert" culture era of the XVIII century. Concert aria is an unique vocal genre having to completely downgrade over time, in connection with certain development of era aesthetics, composition needs, and taste of public. The first determining of the notion genre for concert aria occurs in the middle of the $19^{\text {th }}$ century. Herewith emphasize, that only G. Schilling revealed certain distinctions from the opera aria, as well as underlined singular, specialized features of performing for this genre.

The key words: musical genre, vocal music, concert aria, opera, classical era, singer.

Постановка проблеми. Відомо, що важливою складовою фестивально-конкурсної, концертної, а також педагогічної діяльностей сфери вокального академічного мистецтва постає відповідний художній репертуар. Його значення для певного мистецького напряму складно переоцінити, адже саме музичний твір зумовлює професійно-виконавську своєрідність артиста, позначену як самобутністю художньо-образного відтворення змісту вокальної композиції, так і технологічно-практичною специфікою академічного співу.

Націленість на результат (педагогічний, виконавськосценічний) визначає складний процес добору того чи іншого вокального твору. I саме тут виникає проблема освіченості митця в питаннях історії та теорії музичного мистецтва, особливостях розвитку певних музичних жанрів, стилів, напрямів тощо.

Концертна арія, 3 іiі надзвичайно високим технологічновиконавським рівнем вокальної культури, що формує суттєву педагогічну та концертно-сценічну вагу окресленого жанру, значною мірою акцентує питання щодо історії виникнення цього 
жанрового феномену, його розвитку в історично-дослідницькій ретроспективі.

Актуальність дослідження. Перед сучасними виконавцямивокалістами високопрофесійного академічного напряму постає питання формування цілісного сприйняття означеного жанру, утворення крізь призму даного жанрового феномену нового бачення та оновлених акцентів на музичну культуру XVIII століття.

Огляд літератури. Науковий матеріал статті виходить зі спроби узагальнити досвід видатних музикознавців та вчених, насамперед моцартознавців, а саме Г. Аберта [1], І.П. Сусідки [3], П.В. Луцкера [3], Г. Шиллінга [5], К. Висоцькі [6] та деяких інших дослідників.

Мета статті полягає у дослідженні та виявленні певних історичних етапів розвитку жанру концертної арії, а також сформуванні загальних причин зародження феномену окресленого жанру.

Об'єктом дослідження постає жанр концертної арії в музичній культурі класицизму, а предметом - історичні особливості розвитку концертної арії як музичного жанру.

Виклад основного матеріалу. Перш за все, слід з'ясувати визначення терміну. Зазвичай, під концертною арією мається на увазі твір для голосу в супроводі оркестру, а нерідко і декількох інструментів. За типом вокального викладу концертна арія споріднена з оперною, але з тих чи інших причин, відокремившись від загальної драматургії, отримала статус самостійного твору.

У наш час до концертних арій належать такі вокальні твори: самостійні арії (для концертного виконання), вставні арії (використовувались в операх інших композиторів), арії доповнення (написані композитором для власних творів), apiï licenze (хвалебна арія або речитатив, що виникла у другій половині XVII століття й призначалась для вшанування представників вищої знаті) і деякі інші різновиди. Арія licenze зазвичай звучала у фіналі дії або всієї опери та не мала сюжетної єдності з цим твором.

Але ж поняття визначення концертної арії та творів, які належали до цього жанру, з плином часу змінювались.

Починаючи з XVIII і до початку XIX століття таке поняття як „концертна арія” не було визначено конкретно. Цей жанр іноді розуміли як віртуозну оперну арію, або як самостійний твір для 
виконання у концерті. Вперше термін „концертна арія” отримав визначення в середині XIX століття, у праці Густава Шиллінга $[5,261]$, який відзначав особливістю жанру лише його виконання на концертній сцені.

Тільки наприкінці XX - початку XXI століття жанр „концертної арії” став існувати як окремий, самостійний твір, який композитор створював для конкретного виконавця, або як вставний номер для власних або чужих опер. У цей період музикознавці проводять дослідження цього жанру для виявлення музичних особливостей, а також проблематики їх виникнення.

Феномен зародження концертної арії розвертається в традиціях барочної вистави і в самій естетиці опери seria. Суть естетики полягала в особливому положенні арій-афектів, в яких основну роль займав музичний початок, а також вокальні переваги виконавця у da саро, що приводило до певної статичності на дієвому рівні.

У класичну епоху було особливе захоплення і ставлення до вокальної музики. У другій половині XVIII століття на перший план виходила музика, яка створювалась для людського голосу, а інструментальній відводилась другорядна роль, менш значна.

Центральними фігурами культурного середовища того часу були примадонни, співаки-віртуози, кастрати, які прагнули справити грандіозне враження на публіку, а також показати власні вокально-технічні можливості. Цей факт можна віднести до одного з етапів становлення концертної арії як жанру.

Співаки, в гонитві за славою i особливою повагою, прагненням продемонструвати слухачеві все найкраще у своєму вокальному таланті, звертались до композиторів за індивідуальними творами, які максимально повно розкривали б особливості їх обдарованості, їх вокальну виконавськотехнологічну майстерність.

Композитори також були зацікавлені у становленні нового вокального жанру. Саме у творчості В.А. Моцарта концертна арія досягла кульмінації свого розвитку. У творчому спадку композитора 65 концертних арій, з них 55 збереглись повністю, інші твори доступні лише фрагментарно або зовсім втрачені.

Окрім В.А. Моцарта (вокальні шедеври видатного майстра „Vado ma Dove?”, „Giunse alfin il momento al desio” та ін.), подібні 
apiї створювали як німецькі, так й італійські композитори, а саме Йоганн Крістіан Бах (1735 - 1782), Франц Йозеф Гайдн (1732 1809) та його брат Йоганн Міхаель Гайдн (1737 - 1806), Антоніо Сальєрі (1750 - 1825), Людвіг ван Бетховен (1770 - 1827), Карл Марія фон Вебер (1786 - 1826), Джоаккіно Россіні (1792 - 1868) та ін. Однак їхній внесок у розвиток концертної арії як жанру є досить скромним.

Вже у другій половині XIX століття жанр концертної арії прийшов до занепаду. У чому полягали причини кризи жанру, в цілому, не відомо. Але, мабуть, можна погодитися із мистецтвознавцем К. Висоцькі, яка стверджує, що причиною стала „природна і неминуча еволюція стилю музично-драматичної мови, яка супроводжувалась становленням i розвитком форм, більш орієнтованих на смаки й музичні структури нової епохи" [6, 33-34].

Вагомі зміни в естетичних поглядах публіки, іiі смаки, означили завершення цілої епохи, яскравого періоду насолоди унікальним музичним інструментом - людським голосом. На композиторів і слухачів перестають справляти враження лише вокально-технічні можливості виконавця, на співака покладається нова роль: вокаліст-актор, який повинен повною мірою передати не тільки красу голосу, але й емоційний стан героя.

Прагнення композиторів досягти більшої драматургічної цілісності оперної вистави, тенденція до наскрізного розвитку також призводять до поступової відмови у виконанні й написанні концертних арій. На зміну віртуозній барочній мелодиці прийшла лірична, позбавлена переповненості різними виконавськотехнологічними вокальними прикрасами.

У часи сьогодення становище жанру концертної арії знаходиться скоріше в занепаді, ніж у розвитку (з позиції музикознавчої вивченості та виконавського звернення). Це зумовлено певними особливостями культури епохи XXI століття, які не націлені на виділення індивідуальності виконавця (що навпаки, дало певний поштовх до виникнення концертної арії у XVIII столітті).

Висновки. Концертна арія - унікальний музичний жанр, який виник в епоху класицизму, та саме у цей час досяг свого апогею. Перше визначення терміну жанру концертної арії припадає на середину XIX століття, лише Г. Шиллінг виявив певні відмінності 
означеного жанрового феномену від оперної арії та визначив відповідні особливості виконання творів окресленого жанру.

Перспективи дослідження. Вивчення жанру концертної арії актуальне та необхідне у вітчизняній музикознавчій практиці, як i подальше поглиблення в дослідження, виявлення певних стильових особливостей виконання композицій означеного жанру.

\section{Список використаних джерел і літератури:}

1. Аберт Г. В.А. Моцарт. Москва: Музыка, 1988. 608 с.

2. Жаркова В.А. Концертные арии: традиции жанра и их претворение в творчестве В.А. Моцарта // Музыковедение: сб. науч. ст. Киев, 2012. Вып. 8. C. $36-42$.

3. Луцкер П.В., Сусидко И.П. Моцарт и его время. Москва: Классика-XXI, 2008. $624 \mathrm{c}$.

4. Нагина Д.А. Концертные арии В.А. Моцарта: особенности жанра // Старинная музыка: сб. науч. ст. Киев, 2013. Вып. 2. С. 22-25.

5. Schilling G. Encyclopädie der gesamten musikalischen Wissenschaften oder Universal-Lexiconder Tonkunst. Stuttgard: Verlag von Franz Heinrich Köhler, $1838.768 \mathrm{~s}$.

6. Wysocki C. Le arie da concerto di Wolfgang Amadeus Mozart per voce di soprano. Lucca, 2006. $302 \mathrm{~s}$.

\section{References:}

1. Abert, G. (1988). V.A. Mozart. Moskva: Muzyka [in Russian].

2. Zharkova, V.A. (2012). Concert arias: the traditions of the genre and their implementation in the work of V.A. Mozart. Muzykovedenie, 8, 36-42 [in Russian].

3. Lucker, P.V., Susidko, I.P. (2008). Mozart and his time. Moskva: Klassika-XXI [in Russian].

4. Nagina, D.A. (2013). Concert arias Mozart: features of the genre. Starinnaja muzyka, 2, 22-25 [in Russian].

5. Schilling, G. (1838). Encyclopedia of the entire musical sciences or Universal Lexiconder Tonkunst. Stuttgard: Publisher of Franz Heinrich Köhler [in German]. 6. Wysocki, C. (2006). Le arie da concerto di Wolfgang Amadeus Mozart per voce di soprano. Lucca [in Italian]. 